\title{
New Perspectives for a Sustainable Nutrition of Poultry and Pigs
}

\section{Editorial}

Nowadays a growing number of countries suffer overconsumption of food with increasing concern for food-related waste production both from vegetable sources or other sources derived from production cycles with relative related resource problems, environmental concerns and economic losses. In this view EU Commission outlines as providing a sustainable economy and valuable foods and feeds, both for human and animals, is a key point strategy for future development.

\section{Growing population and increasing environmental burden}

Agricultural resources in the next future will be not enough to provide food for everyone: due to the major shift of the diets to increasing consumption of animal products, the demand for meat and milk will be strongly increased with the larger part derived from developing countries [1]. The livestock production occupies

about $75 \%$ of all agri-cultural lands, consuming approximately $8 \%$ of global human water use [2] with a higher water footprint than plant-based foods [3] that couples with the rising fuel-feedfood competition. European Commission supposes a total food loss in the EU 27 of more than 126 Mt by 2020 with an increasing environmental burden related to resource consumption and pollutant emission from food waste production during the supply chain [4].

Throughout different initiatives, EU strictly recommends a food waste reduction in the next future by increased resource efficiency and integrated product policies. This approach follows the aim of bio-economy [5] to solve the competition for nutritional sources, to improve the sustainability and the productivity of terrestrial livestock systems, to convert the biomass into a range of high-quality foods and to lead to a "zero waste" society and economy, with the development of an "industrial symbiosis".

\section{Conventional unsustainable protein sources}

At the moment the nutritional regimes for meat production from livestock are based on poor sustainable and not environmental friendly vegetable or animal-derived sources. In animal nutrition, protein sources must have a high-protein content, an adequate amino acid profile, and a high level of digestibility [6] to fulfil the nutritional requirements for growth. In this view, fish meal and soy meal are often the most provided protein sources. Anyway these feeds are among the major contributors of land occupation, primary production use, acidification, climate change, energy use, and water dependence [7].

Moreover, imbalances between essential and nonessential amino acids in these feeds often require the addition of exogenous amino acid sources in the diet of monogastrics, such as poultry and pigs such as synthetic compounds that lead to higher production

Eolume 3 Issue 3 - 2016
Agazzi A ${ }^{1 *}$, Invernizzi G² and Savoini G ${ }^{1}$
${ }^{1}$ Dipartimento di Scienze veterinarie per la salute, la
produzione animale e la sicurezza alimentare, Università degli
Studi di Milano, Italy
${ }^{2}$ Università Telematica San Raffaele, Roma, Italy
*Corresponding author: Alessandro Agazzi, Dipartimento
di Scienze veterinarie per la salute, la produzione animale
e la sicurezza alimentare, Università degli Studi di Milano,
Milano, Italy, via Celoria 10, 20133 Milan, Italy, Tel: +39
0250318038; Fax: +39 0250317819; Email: alessandro.
agazzi@unimi.it
Received: May 03, 2016 | Published: May 09, 2016

costs. In such conditions new renewable and environmentalfriendly protein sources are needed to lower costs for animals rearing and meat production.

\section{Sustainable proteins from insects}

On world basis insects are considered as a possible new protein source for animal nutrition due to the high nutritional protein content and amino acid balance [8], beside their possible role in increasing food security [9]. Insects can be fed different by-products, including vegetable waste, whose elimination has an economic and environmental cost. In this way vegetable waste is transformed into a high-protein feed that can replace more expensive feed ingredients, such as fish meal or synthetic amino acid compounds. Moreover insects are quite efficient food converters: it has been estimated that one $\mathrm{kg}$ of insect biomass can be produced from on average $2 \mathrm{~kg}$ of feed biomass [10]. Generally insect meals are characterized by a high quality and quantity of protein [11] with a considerable content of essential amino acids such as lysine methionine and leucine, which are the most frequent limiting amino acids for growth. The insect meal includes also a valuable amount of lipids with an interesting content of polyunsaturated fatty acids from omega 3 and 6 series, which can not only influence the final composition of animal lipids and subsequently the meat quality, but also provides positive effects on the health status of the animals $[12,13]$.

Nowadays two of the most important insects used to produce meal belong to two fly types: Black soldier fly (H. illucens) and housefly larvae. At the moment the most interesting seems to be H. illucens, which has been proposed since the 1990s to convert organic waste into a protein-rich and fat-rich biomass for animal livestock feeding, biodiesel production and chitin production $[9,14]$. Moreover the larvae stadium of black soldier fly has been 
suggested to contain some natural antibiotics [15]. Black soldier fly larvae contain about $40-44 \%$ crude protein being the amount of fat variable depending on the type of diet (15-49\%; [16]). Generally larvae are also characterized by a high Ca and P content (5-8\% DM and 0.6-1.5\% DM, respectively) [17] with also a high lysine content (6-8\% of the CP; [18]).

\section{Insect meal in monogastrics nutrition}

In poultry and pig nutrition the supply of essential amino acids to grow rapidly in a short period of time is a key factor. For this reason soybean meal-based diets, as the major protein source of the diet, are supplied together with fish meal that covers any amino acid deficiency from vegetable proteins [19]. The interest in the use of insect meal in poultry started during '70 and ' 80 , when a number of studies were conducted to evaluate growth, feed:gain and the taste of meat produced. Subsequently, new researches have been performed starting from 2000 [20-23]. Generally available literature confirms the feasibility of total or partial replacement of fishmeal with insect meal. In particular, no negative effects have been reported on growth of insect meal-fed animals, however most of papers have described similar or even better growth rates in chicks when compared to soybean meal or soybean meal plus fishmeal. In the same way the digestibility of nutrients seems to be unaffected, or at least improved, by the use of insect meal in poultry diet when compared with fishmeal: this is especially true when insect meal has a comparable amino acid profile and replaces the whole fish meal in the diet $[20,21]$ determining some economical positive effects [23].

If a number of works can be found on the inclusion of different insect meals in the diet of poultry, not the same happen for swine nutrition: at the moment there are few scientific studies on the use of insects as alternative feed for pigs. Makkar et al. [18] published an exhaustive state-of-the art review on the use of insect meals in livestock nutrition, including pigs and poultry. The authors concluded that Black soldier larvae meal is a suitable ingredient in growing pig diets, being especially valuable for its amino acid, lipid and Ca contents, and with the same palatability of the diet as for soybean meal based rations. On the poultry side, $H$. illucens was able to support good growth rates suggesting higher feed conversion efficiency of diet on the basis of similar growth performance but lower feed intake.

\section{What still to do}

Unfortunately no exhaustive information can be found on the influence of dietary insect meal on digestibility and microbioma changes in the gut both for poultry and pigs. Some resources found that insect meal to pig could negatively affect apparent digestibility of dry matter, if compared with a soybean meal-based diet, although no discrimination of choice between insect meal diet or soybean diet was observed over treated pigs [24]. Anyway it is difficult to understand the efficacy of insect meals because of the lack of available data or, at least, for the different species used depending on the available insect in the country. For a complete understatement of the mechanism of action of insect meal, some steps are still missing such as an exhaustive characterization from a proteomic point of the insect meal used though a deeper approach to the nutritional significance of these innovative dietary compounds such as the use of RNA-sequency (RNA-seq) in the intestine and specifically ileum as the major site of digestion of nutrients. Starting from Freeman et al. [25], who gave a detailed gene expression of the gastrointestinal tract among other porcine tissues, few data are available for RNA-seq on swine and poultry and more specifically on the use of insect meal in these species $[26,27]$, but obtained results suggest distinct expression patterns and network in the intestine with significant variation in gene expression that may modify the development of gastrointestinal cells.

\section{References}

1. FAO (2011) World Livestock 2011 - Livestock in Food Security. Food and Agriculture Organization of the United Nations (FAO), Rome, pp. 1-130.

2. FAO (2009) How to feed the world in 2050. Paper presented at the High Level Expert Forum, Rome, Italy, p. 1-35.

3. Mekonnen MM, Hoekstra AY (2012) A global assessment of the water footprint of farm animal products. Ecosystems 15: 401-415.

4. European Commission (2010) Preparatory Study on Food Waste across EU 27, Report e 2010 e 054. European Commission, 2011. Roadmap to Resource Efficient Europe. COM (2011) 571final, pp. 1-117.

5. European Commission (2012) Innovating for Sustainable Growth: a Bioeconomy for Europe. COM (212) 60final, p. 1-9.

6. Barrows FT, Bellis D, Krogdahl A, Silverstein JT, Herman EM, et al. (2008) Report of plant products in aquafeeds strategic planning workshop: an integrated interdisciplinary roadmap for increasing utilization of plant feedstuffs in diets for carnivorous fish. Rev Fish Sci 16(4): 449-455.

7. Mungkung R, Aubin J, Prihadi TH, Slembrouck J, van der Werf HMG, et al. (2013) Life cycle assessment for environmentally sustainable aquaculture management: a case study of combined aquaculture systems for carp and tilapia. J Cleaner Prod 57: 249-256.

8. Premalatha M, Abbasi T, Abbasi T, Abbasi SA (2011) Energy-efficient food production to reduce global warming and ecodegradation: the use of edible insects. Renew Sustain Energy Rev 15(9): 4357-4436.

9. van Huis A, Van Itterbeeck J, Klunder H, Mertens E, Halloran A, et al. (2013) Edible Insects - Future Prospects for Food and FeedSecurity. FAO Forestry Paper 171, pp. 1-171.

10. Collavo A, Glew RH, Huang YS, Chuang LT, Bosse R, et al. (2005) House cricket small-scale farming. In: Paoletti MG (Ed.), Ecological Implications of Minilivestock: Potential of Insects, Rodents, Frogs and Snails. Science Publishers, New Hampshire, pp. 519-544.

11. Ladron de Guevara O, Padilla P, Garcìa L, Pino JM, Ramos-Elorduy J (1995) Amino acid determination in some edible Mexican insects. Amino Acids 9(2): 161-173.

12. Agazzi A, Cattaneo D, Dell'Orto V, Moroni P, Bonizzi L, et al. (2004) Effect of administration of fish oil on aspects of cell-mediated immune response in periparturient dairy goats. Small Rum Res 55(1-3): 77-83.

13. Farina G, Cattaneo D, Lecchi C, Invernizzi G, Savoini G, et al. (2015) A Review on the Role of EPA and DHA Through Goat Nutrition to Human Health: Could they be Effective both to Animals and Humans? J Dairy Vet Anim Res 2(2): 00027.

14. Diener S, Zurbrügg C, Roa Gutiérrez F, Nguyen Dang Hong MA Koottatep T, et al. (2011) Black soldier fly larvae for organic waste treatment-prospects and constraints. In: Waste Safe $2011-2^{\text {nd }}$ Int. Conf. on Solid Waste Management in the Developing Countries, 13-15 February, Khulna, Bangladesh, pp. 52-59.

15. Newton GL, Sheppard DC, Burtle G (2008) Black Soldier Fly Prepupae: A Compelling Alternative to Fish Meal and Fish Oil. Public Comment on Alternative Feeds for Aquaculture, p. 1-5. 
16. Arango Gutierrez GP, Vergara Ruiz RA, Mejia Velez H (2004) Compositional, microbiological and protein digestibility analysis of larval meal of Hermetiaillucens (Diptera:Stratiomyidae) at Angelopolis-Antioquia, Colombia, Rev - Facult Nacl Agron Med 57: 2491-2499.

17. Yu GH, Chen YH, Yu ZN, Cheng P (2009) Research progress on the larvae and prepupae of black soldier fly Hermetia illucens used as animal feedstuff. Chinese Bull Entomol 46: 41-45.

18. Makkar HPS, Tranb G, Heuzéb V, Ankersa P (2014) State-of-the-art on use of insects as animal feed. Animal Feed Science and Technology 197: 1-33.

19. Miles RD, Jacobs JP (1997) Fish Meal Understanding Why This Feed Ingredient is so Valuable in Poultry Diets. University of Florida Cooperative and Extension Service. Institute of Food and Agricultural Science, USA, p. 1-3.

20. Khatun R, Howlider MAR, Rahman MM, Hasanuzzama M (2003) Replacement of fish meal by silkworm pupae in broiler diets. Pak J Bio Sci 6(11): 955-958.

21. Khatun R, Azmal SA, Sarker MSK, Rasid MA, Hussain MA, et al. (2005) Effect of silkworm pupae on the growth and egg production performance of Rhode Island Red (RIR) Pure line. Int J Poult Sci 4(9): 718-720.
22. Ljaiya AT, Eko EO (2009) Effect of Replacing Dietary Fish Meal with Silkworm (Anaphe infracta) Caterpillar Meal on Performance, Carcass Characteristics and Haematological Parameters of Finishing Broiler Chicken. Pak J Nutrit 8(8): 850-855.

23. Okah U, Onwujiariri EB (2012) Performance of finisher broiler chickens fed maggot meal as a replacement for fish meal. J Agri Tech 8(2): 471-477.

24. Newton GL, Booram CV, Barker RW, Hale OM (1977) Dried Hermetia illucens larvae meal as a supplement for swine. J Anim Sci 44(3): 395400 .

25. Freeman TC, Ivens A, Baillie JK, Beraldi D, Barnett MW, et al. (2012) A gene expression atlas of the domestic pig. BMC Biol 10: 90.

26. Mach N, Berri M, Esquerré D, Chevaleyre C, Lemonnier G, et al. (2014) Extensive Expression Differences along Porcine Small Intestine Evidenced by Transcriptome Sequencing. PLoSOne 9(2): e88515.

27. Smith SH, Wilson AD, Van Ettinger I, MacIntyre N, Archibald AL, et al. (2014) Down-regulation of mechanisms involved in cell transport and maintenance of mucosal integrity in pigs infected with Lawsonia intracellularis. Vet Res 45: 55. 